\title{
Stewardship And Financial Performance In Wide-Moat Firms
}

David P. Boyd, Northeastern University

Mustafa Yilmaz, Northeastern University

\begin{abstract}
Previous research has shown that the historical appreciation of Morningstar wide-moat companies exceeds that of benchmark indices. In the case of mutual funds, prior work has also demonstrated the significance of Morningstar's stewardship grade in partially explaining such out performance. The present study examines 181 wide-moat companies and assesses whether stewardship has a comparable influence on the financial performance of individual firms.
\end{abstract}

\section{INTRODUCTION}

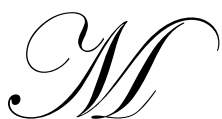

orningstar accords wide-moat status sparingly, conferring it on only 181 firms as of August 2007. Previous research has demonstrated the financial ascendancy of these firms over time (Boyd \& Quinn, 2006). The reasons for this prolonged prowess merit attention. In particular, is stewardship of investor capital a contributing factor? The early part of this decade afforded many examples where egregious illegality induced financial free-fall. Enron's stock was trading over $\$ 80$ per share in January of 2001. A year later it had plunged to less than 70 cents per share. Clearly, stewardship run amok can hurt a firm's performance, but can responsible stewardship bolster it?

Studies that address this issue are limited in number and variant findings have been adduced. For example, Gompers, Ishii and Meltrick (2003) find a positive relationship between corporate governance and growth in earnings, revenues and share price. Their so-called "democracy portfolio" outperformed their "dictatorship portfolio" by nine percent per year from 1990 to 1999. Yet following the same approach as Gompers et.al, Bauer, Guenster and Otten (2003) found a negative relationship between corporate governance and performance ratios. In another more selective and focused study, Cremairs and Nair (2005) found one external and one internal governance mechanism were consistently associated with abnormal returns over time. These two mechanisms of takeovers and active shareholders exhibited a strong complementary interaction. While causal links are always difficult to claim, other studies (Aggarwal \& Williamson, 2006; Belchuk \& Cohen, 2005) suggest that better governance may cause higher firm value.

\section{WIDE-MOAT FIRMS}

Morningstar posits four fundamental criteria that bestow wide-moat designation. These criteria are (1) infrastructure and economies of scale, (2) customer retention via barriers to switching, (3) intangible assets of intellectual property, and (4) network economics. When collectively present, these structural characteristics imbue a firm with sustainable competitive advantage.

Economies of scale allow a firm to leverage infrastructure and achieve low-cost advantage. Even after its products have been relegated to commodity status, such firms can utilize their position as low-cost provider to exert pricing pressure. High-switching costs for customers represent another barrier to encroachment by rivals. For example, complex technology systems or medical products often require a steep learning curve. The commitment expended for adoption militates against defection. 
A third advantage accrues from intangible assets that enjoy patent protection or exclusive agreements. For a specified period of time at least, the cloning crowd is kept at bay and deterred from purloining intellectual property. Network economics represent the final hallmark of a wide-moat firm. Herein lies the appeal of a virtual community and the Internet. As more users are drawn to an electronic exchange, transactions increase. This is why Microsoft paid handsomely for its Facebook stake. Based on Microsoft's \$240 million investment, the fledgling networking site is worth $\$ 15$ billion dollars, a valuation that is 500 times earnings.

For the firms it rates on economic moats, Morningstar assigns one of three designations, namely, wide, narrow, or none. Aside from the difficulty of a precise assessment of the underlying criteria for a given company, such assessments can change over time. In August 2007, Morningstar had assigned the wide-moat designation to 181 firms, and more than 900 companies were classified as narrow-moat. To its credit, Morningstar admits that, due to intrinsic assessment difficulties, not all classifications may appear obvious or uncontroversial. To mention a few examples, wide-moat companies include Avon, Equifax, John Wiley, Nike, Weight Watchers, and Qualcomm.

\section{CASTLE MOATS}

The forerunners of castle moats trace to French fortifications situated on a hill or mound. In the process of raising the earth to build the mound, builders created a "motte" around the base. The French word was later translated into the English "moat." During the 1100s castle moats appeared in Europe as the Plantagenet kings showcased their medieval might. Castles were typically situated near a water supply; a dam controlled the moat flow, often allowing a depth of 30 feet and a width of 12. The water prevented invaders from "sapping" or tunneling to induce collapse of the castle walls. For nearly four centuries these stone castles towered like grand sphinxes.

Nor were such edifices a strictly European phenomenon. Japanese castles refined the defensive concept to include multiple moats arranged in a series of concentric circles. Even today the Japanese Imperial Palace comprises a bustling body of water while Beijing's Forbidden City boasts a large moat 52 meters broad. In these contemporary instances moats no longer serve as tools of warfare. Nonetheless, the moat's role as a line of defense remains more than historical artifact. In an attempt to thwart intrusion after 9-11, the Catawba Nuclear Generating Station in South Carolina designed a concrete moat around the non-water part of the plant's periphery.

\section{GRADING STEWARDSHIP AND CORPORATE GOVERNANCE}

In the wake of the mutual fund scandal, Morningstar developed and launched in 2004 a construct predicated on the sanctity of stewardship. The purpose was to determine "how seriously the mutual fund company takes its fiduciary responsibility to mutual fund investors" (Subramanian, 2004, p. 1). Morningstar awards stewardship grades on a scale from A (excellent) to F (very poor). In determining the overall grade, Morningstar considers a variety of quantitative and qualitative factors, including corporate culture. As stewards of investor capital, managers should eschew high fees and embrace transparent communication. Above all, the true north of corporate culture is fixation on long-term performance rather than "du jour" trends. In evaluating corporate culture, Morningstar is favorably disposed toward funds that are investment-oriented rather than sales-oriented. In its newest and slightly revised iteration of the grading system, corporate culture will comprise nearly 40 percent of a fund's overall stewardship grade (previously, all components were equally weighted). By assigning more weight to this component, Morningstar acknowledges that corporate culture is the most instrumental determinant of how well a fund serves investors (Lutton, 2007).

Following in the footsteps of its stewardship grading approach for mutual funds, Morningstar extended its concept to individual companies in 2005. In its current version, letter grades are assigned on the basis of four criteria: (1) Transparency, (2) Board independence, (3) Incentives and ownership, and (4) Shareholder friendliness. The first rubric highlights accounting practices and financial disclosure. Board independence considers whether the roles of Chairman and CEO are separated and flags any related-party transactions. It attempts to assess the Board's ability to act in the best interest of all shareholders (rather than being guided by the CEO, for example). Incentives and ownership category seeks evidence of equity ownership by managers and directors. "Skin in the game" increases the likelihood that managers will remain attentive to their fiduciary duty. On the other hand excessive 
incentives, such as options or restricted stock, might signal that management is giving away too much of the firm. Morningstar looks askance on compensation packages that "reward managers for being employed rather than for making value-enhancing decisions" (Dorsey, 2005, p. 2). The fourth component focuses on the ability of shareholders to affect the company's structure and policies. For example, as proponents of shareholder friendly management, Morningstar takes exception to cumulative or majority voting rights as well as the presence of poison pills.

Unlike the stewardship grades for funds, Morningstar does not reveal a clear, quantified method for assigning stewardship grades for stocks. As a result, only an aggregate grade is provided. Morningstar emphasizes that, unlike some corporate governance grades provided by other financial research organizations, its letter grades are "absolute." The grade assigned to a stock is based strictly on the information available for that stock, and it is not rendered as a relative ranking among other stocks similarly evaluated. An example of the latter type of "relative" evaluation, introduced in 2002 by Institutional Shareholder Services (ISS), is the Corporate Governance Quotient (CGQ). This quotient ranks more than 8000 companies on as many as 63 individual corporate governance variables. Categories for evaluation encompass board of directors, audit, charter and bylaw provisions, antitakeover provisions, executive and director compensation, progressive practices, ownership, and director evaluation. A stock's CGQ in this system is actually a percentile, that is, the percentage of all stocks having a lower CGQ than the given stock. Consequently, ISS Quotients are relative to other firms being evaluated whereas Morningstar grades are independent of them. For instance, if all firms are evaluated as poor in their corporate governance practices, they would all receive poor letter grades in the Morningstar system; however, some would receive top rankings in the ISS system. Finally, Morningstar assigns no scores to American Depository Receipts, and ISS excludes most foreign firms.

Our analyses were motivated by the following three specific questions:

Q1. Is the Morningstar Stewardship Grade significantly correlated with some common financial performance measures?

Q2. Is the ISS Corporate Governance Quotient significantly correlated with some common financial performance measures?

Q3. Is there some consistency between Morningstar Stewardship Grades and ISS CGQ, that is, are they significantly correlated?

\section{FINDINGS}

We used data for the following variables in our analyses:

Stewardship measures:

Morningstar Stewardship Grade

ISS Corporate Governance Quotient

Financial performance variables:

3-Year stock appreciation

5-Year stock appreciation

3-Year revenue growth

3-Year net income growth

3 -Year earnings per share growth

Except for ISS CGQ, data for these variables are available at the Morningstar website www.morningstar.com. Data for ISS CGQ can be found at www.yahoo.com. For the 181 stocks designated as wide-moat by Morningstar in August 2007, our main findings are summarized in Table 1 below. In the table, the top number in each cell is the Pearson correlation coefficient between the variables in the row and column headings 
for that cell. Below the correlation coefficient is its observed statistical significance ( $\mathrm{p}$-value). Although the number of non-missing data values in each cell varies, the smallest number of data values was $n=130$ in the top left corner cell where $r=0.073$ with a $p$-value of 0.408 . In all other cells, more than 150 values were available for computing the correlation coefficients and p-values.

Table 1: Pearson Correlation Coefficients Between all Pairs of Variables

\begin{tabular}{|c|c|c|c|c|c|c|}
\hline & $\begin{array}{c}\text { Morningstar } \\
\text { Stewardship } \\
\text { Grade } \\
\end{array}$ & $\begin{array}{c}\text { ISS Governance } \\
\text { Quotient }\end{array}$ & $\begin{array}{l}\text { 3-Year } \\
\text { Return }\end{array}$ & $\begin{array}{l}\text { 5-Year } \\
\text { Return }\end{array}$ & $\begin{array}{c}\text { 3-Year } \\
\text { Revenue } \\
\text { Growth } \\
\end{array}$ & $\begin{array}{c}\text { 3-Year Net } \\
\text { Income Growth }\end{array}$ \\
\hline $\begin{array}{c}\text { ISS Governance } \\
\text { Quotient }\end{array}$ & $\begin{array}{c}\mathbf{0 . 0 7 3} \\
(0.408) \\
\end{array}$ & & & & & \\
\hline 3-Year Return & $\begin{array}{c}\mathbf{0 . 1 0 0} \\
(0.230) \\
\end{array}$ & $\begin{array}{c}\mathbf{0 . 1 0 0} \\
(0.269) \\
\end{array}$ & & & & \\
\hline 5-Year Return & $\begin{array}{c}\mathbf{0 . 0 9 0} \\
(0.279)\end{array}$ & $\begin{array}{c}\mathbf{0 . 0 6 0} \\
(0.509)\end{array}$ & $\begin{array}{c}\mathbf{0 . 7 5 7} \\
(0.000)\end{array}$ & & & \\
\hline $\begin{array}{l}\text { 3-Year Revenue } \\
\text { Growth }\end{array}$ & $\begin{array}{l}\mathbf{- 0 . 0 7 4} \\
(0.357)\end{array}$ & $\begin{array}{l}\mathbf{- 0 . 0 9 8} \\
(0.268)\end{array}$ & $\begin{array}{c}\mathbf{0 . 1 5 4} \\
(0.047)\end{array}$ & $\begin{array}{c}\mathbf{0 . 2 6 0} \\
(0.001)\end{array}$ & & \\
\hline $\begin{array}{c}\text { 3-Year Net } \\
\text { Income Growth }\end{array}$ & $\begin{array}{l}\mathbf{- 0 . 0 8 5} \\
(0.316)\end{array}$ & $\begin{array}{c}\mathbf{0 . 0 8 8} \\
(0.345)\end{array}$ & $\begin{array}{c}\mathbf{0 . 2 0 7} \\
(0.009)\end{array}$ & $\begin{array}{c}\mathbf{0 . 2 0 4} \\
(0.011)\end{array}$ & $\begin{array}{c}\mathbf{0 . 1 9 0} \\
(0.015)\end{array}$ & \\
\hline $\begin{array}{l}\text { 3-Year EPS } \\
\text { Growth }\end{array}$ & $\begin{array}{c}\mathbf{0 . 0 6 4} \\
(0.447)\end{array}$ & $\begin{array}{c}\mathbf{0 . 0 9 5} \\
(0.298)\end{array}$ & $\begin{array}{c}\mathbf{0 . 3 0 9} \\
(0.000)\end{array}$ & $\begin{array}{c}\mathbf{0 . 3 6 7} \\
(0.000)\end{array}$ & $\begin{array}{c}\mathbf{0 . 4 0 1} \\
(0.000)\end{array}$ & $\begin{array}{c}\mathbf{0 . 5 3 3} \\
(0.000)\end{array}$ \\
\hline
\end{tabular}

The correlations in the first two columns of Table 1 are strikingly low, and none comes close to statistical significance. Based on these data, all three questions we posed above must be answered in the negative. For widemoat companies, Morningstar stewardship grades do not correlate with financial performance measures, and the same is true for the ISS Corporate Governance Quotient. Further, there is no correlation at all between Morningstar grades and ISS quotients. In terms of similarity or consistency with each other, the two indicators might as well be randomly drawn from a hat. The only significant correlations in Table 1 are among the financial variables themselves (in the last four columns).

Before condemning corporate America for a surfeit of cynicism, we should qualify the study's suggestive findings. First, by introducing these two stewardship "measures," financial researchers may be generating nothing more than construct "noise" instead of genuinely useful information for investors. The concepts are murky because both the selection and measurement of variables have an arbitrary cast. The concepts of stewardship and corporate governance seem holistically bound yet the precise links are tenuous. One manager captures the integral but elusive connection when he notes that "the bottom line for good corporate governance is that the board must ... verify the management team's stewardship" (Santoso, 2007, p. 3). In sum, the two stewardship measures considered here may not be useful because they are idiosyncratic, somewhat arbitrary, and do not even correlate with each other.

It is worth mentioning that Morningstar's more codified stewardship construct for mutual funds showed some explanatory significance (Boyd \& Yilmaz, 2007). One reason might be that stewardship grades for funds underscored corporate culture while grades for stocks exclude it. The ISS Corporate Governance Quotient also fails to include culture as a variable. Kotter and Heskett (1992) demonstrated a persuasive historical relationship between corporate culture and business performance. More recent studies (e.g., Flamholtz, 2001; Roi, 2006) have validated Kotter's claim about the financial impact of strong leadership and adaptive culture. Morningstar is reviewing and revising its calculation of corporate stewardship. By broadening structural components, Morningstar may bolster the construct's credibility. Emergent models of stewardship may thus prove better barometers of corporate performance. Even if relationships are subsequently found, as always prospective designs will be necessary to determine whether the patterns of the past are an accurate prequel. The rear view mirror may be of limited assistance in steering the car forward. 
A second reason may be that there is a more direct connection between the management of a mutual fund and what the fund offers to investors than there is between the governance of a firm and the products it sells to its customers. Management of a fund selects the stocks in the fund and sets the fees it charges to investors, so stewardship seems relevant. On the other hand, there are usually many more layers between the top management of a firm and the products it sells to its customers, so stewardship may be less relevant. Structural complexity makes stewardship issues less apparent and even if lapses become evident, culpability is harder to assign.

As for the current measures from Morningstar and ISS, investors may not truly care about such issues as whether the board of a firm is entrenched or the CEO also wears the hat of Chairman of the Board. The primary focus may be return. This situation is different from the mutual fund industry where many funds have been tarnished by poor stewardship. Miscreants at the helm abrogated fiduciary duty and unleashed financial havoc. The Governance factor may be less relevant for most individual companies upon whom the spotlight of stewardship does not shine as brightly. As long as investors are making money and CEOs are staying out of jail, stewardship seems peripheral rather than pivotal. For investors of stocks, the salient issue is how well companies succeed rather than how well they are overseen. As ethical agnostics their mindset is denominated in dollars. To them any further consideration would be both spurious and sanctimonious. Even if there are altruists among the lot, they can use their profitable returns to contribute to charities of choice. Thus the social munificence of successful investors is a result of amoral market dynamics. According to this view, social concerns need not inform a firm's action nor play a role in investor selections.

\section{CONCLUSION}

In the aftermath of the subprime debacle, The Wall Street Journal reported that established respected creditrating firms such as S\&P, Moody's and Fitch assigned top ratings to securities built around questionable subprime mortgage loans, making these securities seem as safe as Treasury bonds Lucchetti \& Serena, 2007). While we do not imply that Morningstar and ISS are prone to committing similar misdeeds when they rate stewardship or corporate governance, our findings cast some doubt on the value of the information these ratings convey to investors. Like the firms they grade, companies such as Morningstar and ISS are under pressure to generate business and stay ahead of competitors. In that effort, they promulgate products and services such as these grades and ratings. While it is easy to add to an intellectual inventory of investor information, it is less easy to demonstrate the utility of these new products. Ultimately, investors are responsible for not only arriving at their investment decisions but also for selecting the information they use in those decisions.

\section{REFERENCES}

1. Aggarwal, Reena and Williamson, Rohan, Did New Regulations Target the Relevant Corporate Attributes? www.msb.edu/faculty/agarwal/, Georgetown University, September 2006.

2. Bauer, Rob, Guenster, Nadja, and Otten, Roger, Empirical Evidence of Corporate Governance in Europe: The Effect on Stock Returns, Firm Value and Performance, EFMA 2004 Basel Meetings Paper, October 23, 2003.

3. Bebchuk, Lucian and Cohen, Alma, The Costs of Entrenched Boards, Journal of Financial Economics, Vol. 78, No. 2, pp. 409-433, 2005.

4. Boyd, David P. and Quinn, Robert C., Financial Metrics in Wide-Moat Firms, Journal of Business and Economics Research, Vol. 4, No. 6, 2006.

5. Boyd, David P. and Yilmaz, Mustafa, Stewardship as a Factor in the Financial Performance of Mutual Funds, Journal of Business and Economics Research, Vol. 5, No. 3, 2007.

6. Cremairs, K. J. Martijn and Nair, Vinay B., Governance Mechanisms and Equity Prices, The Journal of Finance, Vol. 60, No. 6, pp. 2859-2894, December 2005.

7. Dorsey, Pat, Introducing the Stewardship Grade for Stocks, Morningstar.com, February 7, 2005.

8. Flamholtz, Eric, Corporate Culture and the Bottom Line, European Management Journal, Vol. 19, No. 3, pp. 268-275, 2001.

9. Gompers, Paul, Ishii, Joy and Metrick, Andrew, Corporate Governance and Equity Prices, The Quarterly Journal of Economics, 118, pp. 107-155, February 2003. 
10. Kotter, John P. and Heskett, James L., Corporate Culture and Performance, Free Press, New York, NY, 1992.

11. Lucchetti, Aaron and Ng, Serena, How Rating Firms' Calls Fueled Subprime Mess, The Wall Street Journal, pp. A1, A10, August 15, 2007.

12. Lutton, Laura Pavlenko, Takeaways from Our Stewardship Grades, Morningstar.com, May 14, 2007.

13. Roi, Richard, Crawford Leadership Study Survey, Crawford and Associates International, Palo Alto, CA, 2006.

14. Santoso, Shirley, Building Up Good Governance Starts With Understanding, The Bangkok Post, June 9, 2005.

15. Subramanian, Sam, Mutual Funds: What Investors Need to Know about Morningstar Fiduciary Grades, AlphaProfit Investments, September 29, 2004.

\section{NOTES}

